University for Business and Technology in Kosovo

UBT Knowledge Center

UBT International Conference

2018 UBT International Conference

Oct 27th, 9:00 AM - 10:30 AM

\title{
The Impact of Activated Carbon at Some Water Wells Parameters
}

\author{
Fidane Feka \\ University for Business and Technology \\ Fisnik Laha \\ University for Business and Technology, fisnik.laha@ubt-uni.net \\ Syzana Aliu \\ University for Business and Technology \\ Hyzer Rizani \\ University for Business and Technology \\ Valon Durguti \\ University for Business and Technology
}

Follow this and additional works at: https://knowledgecenter.ubt-uni.net/conference

Part of the Food Science Commons

\section{Recommended Citation}

Feka, Fidane; Laha, Fisnik; Aliu, Syzana; Rizani, Hyzer; and Durguti, Valon, "The Impact of Activated Carbon at Some Water Wells Parameters" (2018). UBT International Conference. 192.

https://knowledgecenter.ubt-uni.net/conference/2018/all-events/192

This Event is brought to you for free and open access by the Publication and Journals at UBT Knowledge Center. It has been accepted for inclusion in UBT International Conference by an authorized administrator of UBT Knowledge Center. For more information, please contact knowledge.center@ubt-uni.net. 


\title{
The Impact of Activated Carbon at Some Water Wells Parameters
}

\author{
Fidan Feka, Fisnik Laha, Syzana Aliu, Hyzer Rizani and Valon Durguti \\ UBT Higher Education Institution, Lagjja Kalabria p.n., Prishtinë, Kosovë \\ fisnik.laha@ubt-uni.net
}

\begin{abstract}
Increasingly, the demand for quality water is growing, and finding alternative ways for wells water treatment is under way. The purpose of this study is to apply activated carbon at the wells water treatment, whereby several parameters are measured such as $\mathrm{pH}$, electric conductivity, total chlorine and iron, before carbon-activated treatment and after being treated with activated carbon. From the observed testing results, a change in results after the treatment phase was observed: a decrease in electrical conductivity in all samples, as well as in all samples treated we got an increase in $\mathrm{pH}$ value and total chlorine, whereas in the iron property there are some variations in results. Practical laboratory procedures on the water samples treatment with activated carbon has been carried out at the UBT Laboratories, Food Science and Biotechnology Lab.
\end{abstract}

Keywords: Activeted carbon, physico-chemical parameters of wells water.

\section{Introduction}

The active carbon is the primary absorbent used in water treatment, and it is especially used to eliminate odors, tastes and pesticides.

The active carbon adsorption power is derived from high surface energy, which is greater, finer and porous. ${ }^{[3]}$



Figure 1. The active carbon adsorption forms.

The diameter of the active carbon granule is $(2-5 \mathrm{~mm}$ pure $>85 \%)$ It is used in medicine, as disinfection of the gastrointestinal tract during various diseases, because it fixes microorganisms and bacterial toxins, 


\section{Materials and Methods}

$2 \mathrm{dm}^{3}$ of water were obtained for analysis. Prior to the treatment phase, these parameters are defined such as $\mathrm{pH}$, electrical permeability (conductivity), total chlorine and iron. The samples were treated with the active carbon $(1 \mathrm{~g} / 500 \mathrm{ml}) 15 \mathrm{~min}$, and after the treatment phase the respective parameters were determined. The samples were filtered with filter paper "Selekcta" no. 589, (Germany). Practical work is done in UBT laboratory spaces. Appliances include photometers, $\mathrm{pH}$ meters and conductometers. ${ }^{[1],[2] .}$

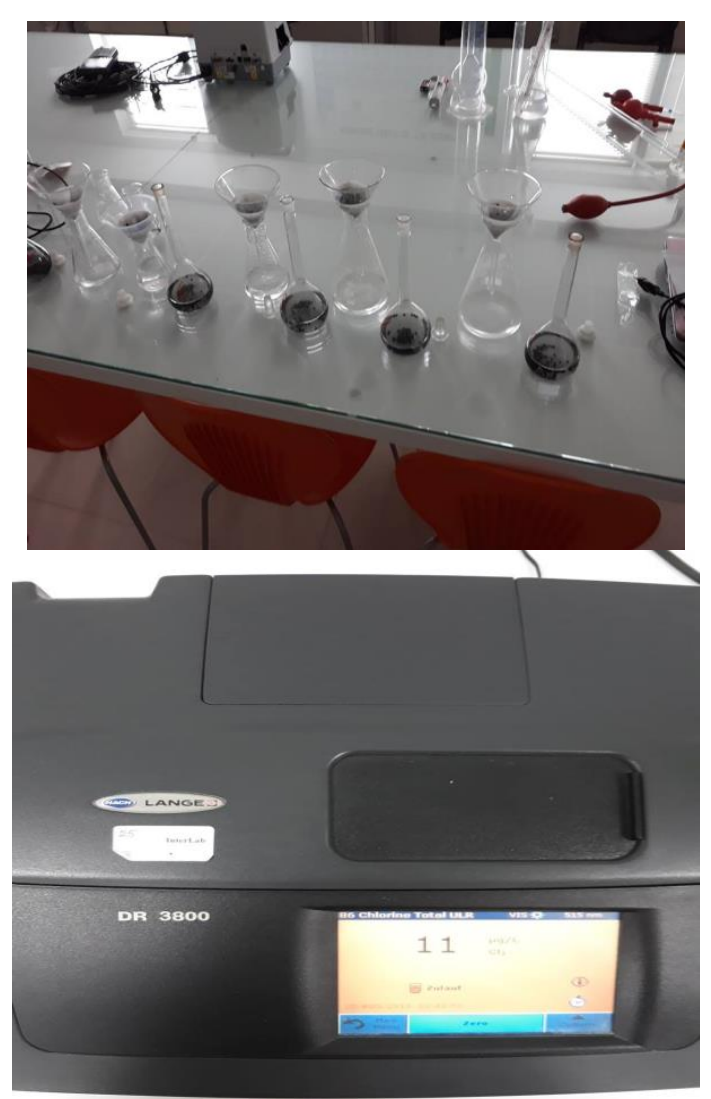

Figure 3. Part of the practical work. 


\section{Results}

Table. 1. Results of the water samples before the treatment phase

\begin{tabular}{|c|c|c|c|c|c|}
\hline $\begin{array}{c}\text { Place of } \\
\text { Sampling }\end{array}$ & $\begin{array}{c}\text { Water } \\
\text { temp. } \\
/{ }^{\circ} \mathrm{C}\end{array}$ & $\begin{array}{c}\text { Stability } \\
\text { elelekt. } \\
/ \text { us cm }\end{array}$ & $\begin{array}{c}\mathrm{Fe} \\
\mathrm{mg} / \mathrm{kg}\end{array}$ & $\begin{array}{c}\mathrm{Cl} / \\
\mu \mathrm{kg} / \mathrm{kg}\end{array}$ \\
\hline $\mathrm{P}_{1}$ & 22.1 & 570 & 6.79 & 0.01 & 37 \\
\hline $\mathrm{P}_{2}$ & 22.1 & 819 & 6.68 & 0.62 & 17 \\
\hline$P_{3}$ & 21.7 & 1100 & 6.66 & 0.09 & 5 \\
\hline$P_{4}$ & 22.0 & 1055 & 6.80 & 0.02 & 11 \\
\hline$P_{5}$ & 21.8 & 1079 & 6.90 & 0.03 & 2 \\
\hline
\end{tabular}

Table 2. Results of the water samples after the treatment phase

\begin{tabular}{|c|c|c|c|c|c|}
\hline $\begin{array}{c}\text { Place of } \\
\text { Sampling }\end{array}$ & $\begin{array}{c}\text { Water } \\
\text { temp. } \\
/{ }^{\circ} \mathrm{C}\end{array}$ & $\begin{array}{c}\text { Stability } \\
\text { elelekt. } \\
/ \text { us cm }\end{array}$ & $\begin{array}{c}\mathrm{Fe} \\
\mathrm{mg} / \mathrm{kg}\end{array}$ & $\begin{array}{c}\mathrm{Cl} / \\
\mu \mathrm{gg} / \mathrm{kg}\end{array}$ \\
\hline$P_{1}$ & 25.5 & 472 & 7.29 & 0.05 & 45 \\
\hline$P_{2}$ & 25 & 568 & 7.20 & 0.06 & 26 \\
\hline$P_{3}$ & 24.7 & 936 & 7.14 & 0.04 & 42 \\
\hline$P_{4}$ & 24.3 & 1033 & 7.06 & 0.07 & 62 \\
\hline$P_{5}$ & 25.4 & 1100 & 7.23 & 0.12 & 58 \\
\hline
\end{tabular}




\section{Discussion}

From the evaluation of the water parameters before the treatment phase and after the activate carbon treatment phase, it resulted that a part of the parameters had a rise in values in all samples, such as $\mathrm{pH}$, total chlorine $(\mathrm{Cl} 2)$ and e it is also normal for the temperature to have a raise, while parameters such as permutation and iron do not have a sustained increase in values. ${ }^{[4]}$

$>$ The total chlorine $(\mathrm{Cl} 2)$ before the treatment phase ranges from $2-37 \mu \mathrm{g} / \mathrm{kg}$, where the highest value is recorded at the site of $\mathrm{P} 1$, whereas after the treatment phase the results vary from $26-58 \mu \mathrm{g} / \mathrm{kg}$, where the highest values have occurred at the site P5.

$>$ Iron, prior to the treatment phase ranges from $0.01-0.62 \mathrm{mg} / \mathrm{kg}$, where the highest value is recorded at the site of $\mathrm{P} 2$, and after the treatment phase the results vary from $0.05-0.12 \mathrm{mg} / \mathrm{kg}$, where the highest values have occurred at the site P5.

$>$ The $\mathrm{pH}$ at all sites has resulted in upsurge whereby it makes us realize that the active carbon can be found in many aspects, either agriculture (in highly acidic and carbonrich soils contributes to lowering acidity).

\section{Recommendations}

From the results achieved for these parameters of activated carbon water we can come up with these conclusions or recommendations such as:

- The application of the active carbon is important for those waters that have expressed acidity and carbon-based treatment reduces acidity in water samples. Also the active carbon can find room for use in other areas that have to do with the $\mathrm{pH}$ value.

- We must be careful about the application of the active carbon and its purity, which may affect variations of many parameters that affect the quality of water or many other products.

- The active carbon is also used in drinking water, and this appliance is used to remove wind and water, but care must be taken because there may be deviations of the results for many parameters.

\section{References}

1. Thomas, R. (2011). Beginner's Guide to ICP-MS. PartsIhttp://www.spectroscopymag.com. 
2. Anthropogenic Sources and their Environmental Impact to Surface Waters. Accepted 20 May 2013, Available online 1June 2013, Vol.3, No.2 (June 2013).

3. https://www.tandfonline.com/doi/abs/10.1080/09593330.2013.846923? journalCode=t ent20.

4. Study of Industrial Discharges in Water of River Lepenci and ChemicalEnvironmental Impact on Public Health. Received 16 November 2012, Received in revised form 6 January 2013, Accepted 8 January 2013, Published 10 January 2013.

5. Çullaj, (2005): Kimia e Mjedisit, FShN, UT, Prof. Alqi Çullaj 2005.

6. Payment, et.al., (2003): Payment P, Waite M, Dufour A. Introducing parameters for the assessment of drinking water quality. London, UK: IWA Publishing; 2003.

Available from:

http://www.who.int/water_sanitation_health/dwq/9241546301_chap2.pdf. 